\title{
PENGEMBANGAN MODEL LAYANAN INFORMASI BERBANTU MEDIA VISUAL UNTUK MENINGKATKAN PEMANTAPAN KARIER PADA SISWA SMA NEGERI DI KABUPATEN KUBU RAYA
}

\author{
Novi Andriati ${ }^{1}$, Riki Maulana ${ }^{2}$, Galuh Hartinah $^{3}$, Ema Sukmawati $^{4}$ \\ ${ }_{1,2,3,4}$ Program Studi Bimbingan dan Konseling \\ Fakultas Ilmu Pendidikan dan Pengetahuan Sosial IKIP PGRI Pontianak \\ Jalan Ampera Nomor 88 Pontianak - 78116, Telepon (0561) 748219 Fax. (0561) 589855 \\ Alamat e-mail: ${ }^{1}$ novieandriaty@yahoo.co.id
}

\begin{abstract}
Abstrak
Tujuan penelitian ini ialah mengembangkan model layanan informasi berbantu media visual untuk meningkatkan pemantapan karier pada siswa SMA, metode yang digunakan dalam penelitian ini adalah metode Penelitian dan Pengembangan (Research and Development). Hasil penelitian: 1) Gambaran pelaksanaan layanan informasi karier di sekolah tempat penelitian sudah dilaksanakan secara umumnya melewati tahapan pendahuluan, kegiatan dan pengakhiran, namun belum pernah menggunakan media tertentu seperti berbantuan media visual yang merupakan media yang dapat mempermudah penyampaian informasi kepada siswa, 2) Desain model yang dikembangkan adalah layanan informasi karier berbantuan media visual terdiri atas enam komponen, yaitu: (a) rasional, (b) tujuan layanan informasi karier, (c) asumsi, (d) target dan isi layanan informasi (e) komponen penunjang layanan informasi karier, dan (f) Langkah pelaksanaan layanan informasi karier berbantu media visual, 3) Model layanan informasi berbantu media visual dapat digunakan sebagai upaya untuk meningkatkan pemantapan karier siswa.
\end{abstract}

Kata Kunci: model layanan informasi; media visual; pemantapan karier;

\begin{abstract}
The purpose of this research is to develop a model of information services assisted by visual media to improve career stabilization in high school students, the method used in this study is the Research and Development method. Results of the study: 1) The description of the implementation of career information services in schools where the research has been carried out generally goes through the stages of introduction, activities and termination, but have never used certain media such as assisted by visual media which is media that can facilitate the delivery of information to students, 2) Model design The development of career information services assisted by visual media consists of six components, namely: (a) rational, (b)career information service objectives, c) assumptions, (d) targets and contents of information services (e) supporting components for career information services, and (f) Steps for implementing career information services assisted by visual media, 3) The visual media assisted information service model can be used as an effort to improve student career stabilization.
\end{abstract}

Keywords: information service models; visual media; career stabilization;

\section{PENDAHULUAN}

Layanan informasi karier merupakan salah satu bentuk pelayanan dalam bimbingan karier yang berisikan sejumlah data, fakta yang dapat menggambarkan keadaan diri seseorang, dengan segala potensinya, ruang lingkup pendidikan dan 
pekerjaan serta seluk beluk persyaratan dan hubungan keduanya. National Career Development Association (NCDA) (Gladding, 2012: 405) mendefinisikan informasi karier sebagai "informasi yang berhubungan dengan dunia pekerjaan yang dapat berguna dalam proses perkembangan karier, termasuk informasi pendidikan, jabatan, dan psikososial yang berhubungan dengan pekerjaan, seperti pelatihan yang disediakan, sifat pekerjaan, dan status pekerja dalam berbagai jabatan". Informasi karier tidak hanya berupa objek faktual, tetapi sebagai kemampuan proses psikologis untuk mentransformasikan informasi yang berkaitan dengan pilihan dan tujuan hidup di masa depan. Kandungan dari informasi karir adalah suatu pelayanan karir yang berusaha membantu individu dalam merencanakan, memilih dan menentukan karir yang akan dijalani. Tugas utama perkembangan remaja ini tentuakan semakin sulit jika tidak diimbangi dengan pengetahuan atau pemahaman yang luas tentang informasi-informasi yang dibutuhkan terutama informasi mengenai pendidikan dan karier.

Menurut Rogers (Suherman U, 2011:118) mengatakan bahwa individu (remaja) akan mengalami masalah dalam kariernya apabila individu berada dalam salah satu kondisi berikut; 1) luas pengetahuan mengenai dirinya tetapi sempit mengenai dunia kerja, 2) sempit pengetahuan mengenai dirinya tetapi luas pengetahuan mengenai dunia kerja, 3) sempit pengetahuan mengenai diri dan dunia kerja, dan 4) luas pengetahuan diri dan dunia kerja. Artinya pengenalan terhadap diri sendiri merupakan hal pokok yang perlu diketahui oleh individu, pengenalan diri berupa memahami bakat, minat dan kemampuan diri, selain itu penguasaan terhadap ilmu pengetahuan merupakan hal penting yang menunjang dalam pencapaian karier termasuk pemahaman mengenai informasi-informasi baik yang berhubungan dengan pendidikan maupun informasi mengenai dunia kerja, tujuan dari semua itu adalah agar individu memahami bagaimana merencanakan karir dengan sebaik-baiknya untuk kemudian mengambil pilihan yang tepat. Memilih dan mempersiapkan diri untuk berkarier merupakan sebuah proses yang berkesinambungan dan tidak terjadi secara tiba-tiba. Proses tersebut diawali dengan ketertarikan individu terhadap suatu pekerjaan, ketertarikan tersebut menjadi awal untuk mendalami dan mencari informasi, selanjutnya mempersiapkan diri melalui 
pendidikan, keikutsertaan dalam berbagai kegiatan, termasuk pemantapan dalam memilih jurusan atau program studi yang menunjang dalam pencapaian karier sehingga pada saatnya memiliki kesiapan untuk berkarier.

Melalui layanan informasi karier melalui media visual, diharapkan siswa dapat menerima dan memahami berbagai informasi yang dapat digunakan sebagai bahan pertimbangan dalam memantapkan pengambilan keputusan kariernya. Jika informasi dan pemahaman tentang karier sudah dipahami sejak dini, maka diharapkan siswa memiliki kenyakinan dalam memilih penjurusan, program studi diperguruan tinggi maupun memiliki pandangan dalam memilih pekerjaan setelah lulus SMA. Media visual yang digunakan merupakan penyampaian pesan atau informasi secara teknik dan kreatif yang mana menampilkan gambar, grafik serta tata dan letaknya jelas, sehingga penerima pesan dan gagasan dapat diterima sasaran. Apabila dikaitkan antara media visual dengan layanan informasi, maka layanan itu akan menarik, efektif dan efesien karena media visual merupakan sumber belajar yang berisikan pesan atau materi yang dibuat secara menarik dalam bentuk kombinasi gambar, teks, gerak dan animasi yang di sesuaikan dengan usia peserta didik yang dapat menarik peserta didik dalam belajar, sehingga membuat siswa menjadi menyenangkan dan tidak menjenuhkan.

Guna memperoleh informasi mengenai bagaimana pelaksanaan layanan informasi karier dilaksanakan oleh guru bimbingan dan konseling di sekolah, dan bagaimana tingkat pemahaman siswa dalam perencanaan kariernya maka dilakukan wawancara dengan beberapa guru bimbingan dan konseling di SMA Negeri Kabupaten Kubu Raya dengan hasil wawancara sebagai berikut: 1) Guru bimbingan dan konseling SMA Negeri 1 Sui Kakap. Wawancara dilakukan pada hari selasa, 12 Februari 2019. Hasil wawancara yaitu: "siswa mendapatkan layanan informasi karir ketika menjelang kenaikan kelas dan ketika kelas tiga karena fokus program layanan bimbingan dan konseling untuk kelas tiga adalah bimbingan dibidang karir melalui layanan informasi yang berisi informasi mengenai pendidikan di perguruan tinggi khususnya dan biasanya disediakan pula brosur-brosur yang berisi informasi mengenai pendidikan tinggi (universitas, institut maupun sekolah tinggi). Sedangkan dikelas satu dan dua tidak difokuskan kepada bimbingan dibidang karir 
tetapi lebih difokuskan kepada bimbingan pribadi, akademik dan sosial. 2) Guru bimbingan dan konseling SMA Negeri 2 Sui Kakap. Wawancara dilakukan pada hari selasa, 14 Februari 2019. Hasil wawancara sebagai berikut: "guru bimbingan dan konseling belum pernah membuat program layanan informasi karir secara khusus, akan tetapi layanan informasi karir pasti diberikan kepada siswa ketika mereka berada di kelas tiga, karena mereka akan menyelesaikan masa studi di SMA dan akan melanjutkan ke pendidikan yang lebih tinggi. Bentuk layanan yang diberikan umumnya adalah layanan secara klasikal dengan materi mengenai perguruan tinggi, jenis pekerjaan, dan pilihan karir, dan materi yang disampaikan juga hampir sama dalam setiap tahunnya, belum pernah membuat variasi kepada materi yang khusus atau menggunakan variasi media dalam penyampaian materi layanan informasi khususnya yang berhubungan dengan karier.

Richma, H (2015) layanan informasi karier membantu peserta didik dalam meningkatkan pemahaman karier. Hasil penelitian menunjukkan layanan informasi ini sangat penting, mengingat bahwa siswa yang menghadapi suatu kesulitan sering membutuhkan informasi tentang lingkungannya. Layanan informasi bertujuan untuk membekali individu dengan berbagai hal yang berguna untuk mengenal diri, merencanakan dan mengembangkan pola kehidupan sebagai pelajar, anggota keluarga, dan masyarakat. Pemahaman yang diperoleh melalui layanan informasi digunakan sebagai bahan acuan dalam meningkatkan kegiatan dan prestasi belajar, mengembangkan cita-cita, menyelenggarakan kehidupan sehari-hari dan mengambil suatu keputusan. Fransiska, P (2018) penerapan layanan informasi karier untuk meningkatkan pemahaman siswa dalam pengambilan keputusan karier. Hasil penelitian menjelaskan bahwa penerapan layanan informasi karir dapat meningkatkan pemahaman pengambilan keputusan karier siswa kelas XII MIPA2, hal ini dapat dilihat pada hasil analisis siklus I dan Siklus II, berdasarkan hasil skor siklus I persentase rata rata yang diperoleh sebesar 62,11\% $(74,5)$ termasuk dalam kategori rendah. Pada siklus II mengalami peningkatandengan persentase 79,58\% $(95,5)$ termasuk dalam kategori tinggi dengan besar peningkatan 17,48\%, artinya pemahaman pengambilan keputusan karir siswa telah memenuhi kriteria yang ditentukan sehingga penelitian tindakan bimbingan konseling pada siklus II telah 
berhasil. Peningkatan aktivitas siswa dalam layanan informasi karier ditunjukkan dengan peningkatan aktivitas siswa dari siklus I ke siklus II adalah 56,58\% (cukup aktif) menjadi $71,32 \%$ (aktif), meningkat $14,74 \%$.

Putu, A \& Sumaryono (2018) kesuksesan karier dan ditinjau dari persepsi pengembangan karier dan komitmen karier pada pekerja milenial. Hasil penelitian menjelaskan tentang persepsi pengembangan karier dan komitmen karier secara bersama-sama memiliki peran dalam meningkatkan variabel kesuksesan karier pada pekerja milenial di hospitality industry sebesar $44.8 \%$. Sedangkan jika dilihat secara parsial variabel persepsi pengembangan karier memiliki peran sebesar 19.4\% dan variabel komitmen karier sebesar $25.70 \%$ terhadap kesuksesan karier. Berdasarkan analisis data demografi ditemukan bahwa tidak terdapat perbedaan kesuksesan karier antara jenis kelamin. Kategorisasi data penelitian menunjukkan bahwa skor variabel persepsi pengembangan karier berada pada kategori tinggi, artinya bahwa responden mempersepsikan pengembangan karier yang ada dalam perusahaan secara baik. Begitu juga pada variabel komitmen karier berada pada kategori tinggi, artinya responden memiliki komitmen karier yang tinggi. Selanjutnya pada variabel kesuksesan karier juga berada pada kategori tinggi, yang artinya bahwa sebagian besar responden memiliki persepsi kesuksesan karier yang baik.

\section{METODE}

Metode yang digunakan dalam penelitian ini adalah metode Penelitian dan Pengembangan (Research and Development), yaitu metode penelitian yang digunakan untuk menghasilkan produk tertentu dan menguji keefektifan produk tersebut. Melalui penelitian dan pengembangan $(R \& D)$ ini, peneliti berupaya untuk menghasilkan dan mengembangkan sebuah model layanan informasi karier berbantu media visual untuk meningkatkan pemantapan karier pada siswa SMA, kerangka dan komponen model dirancang berdasarkan keadaan atau kondisi rill pelaksanaan layanan informasi karier di SMA. Dalam penelitian pengembangan layanan informasi karier berbantu media visual untuk meningkatkan pemantapan karier pada siswa SMA, peneliti tidak melakukan sepuluh langkah penelitian dan 
pengembangan, tetapi hanya sampai pada langkah yang ketujuh, yaitu (1) potensi dan masalah, (2) pengumpulan data, (3) desain produk, (4) validasi desain, (5) revisi desain, (6) uji coba produk, dan (7) revisi produk. Subjek dalam penelitian ini adalah tiga guru bimbingan dan konseling yang sudah berpengalaman melaksanakan layanan bimbingan dan konseling di sekolah dan dua pakar atau ahli di bidang bimbingan dan konseling yang merupakan subjek dalam uji coba model, dan siswa kelas XI SMA Negeri 1 Sui Kakap yang berjumlah 33 siswa. Pelaksanaan layanan informasi dilaksanakan secara klasikal, artinya setiap siswa memiliki kesempatan yang sama untuk mendapatkan layanan informasi yang diberikan oleh guru bimbingan dan konseling di kelas. Gambaran langkah-langkah pengembangan $R \& D$ dapat dilihat pada gambar 1 .

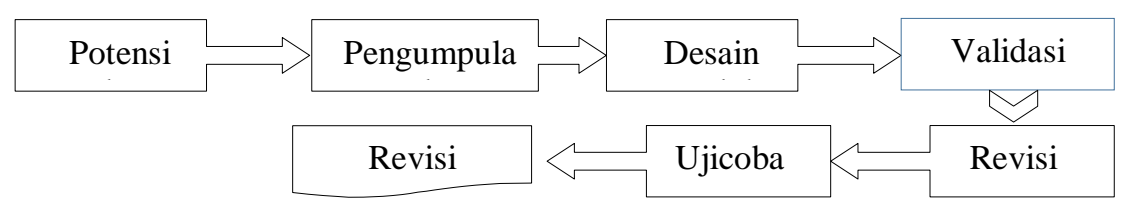

\section{Gambar 1. Langkah-langkah Pengembangan Research and Development}

Teknik pengumpulan data dalam penelitian ini menggunakan teknik komunikasi langsung menggunakan instrumen panduan observasi, pedoman wawancara dan analisis dokumenter, sedangkan teknik komunikasi tidak langsung menggunakan instrumen skala pemahaman karier. Teknik analisi data diperoleh dalam penelitian adalah melalui hasil observasi, wawancara, dan dokumentasi dianalisis secara deskriptif yaitu teknik analisis data dengan cara mendeskripsikan atau menggambarkan data yang telah terkumpul sebagaimana adanya tanpa bermaksud membuat generalisasi hasil penelitian, sedangkan untuk data yang diperoleh dari skala pemahaman karir dianalisis dengan cara statistik deskriptif melalui uji validitas dan reliabilitas. Analisis kelayakan model yang digunakan dalam penelitian ini adalah melalui uji validitas, yaitu validasi ahli oleh dua dosen (pakar/ahli dibidang bimbingan dan konseling) dan validasi praktisi oleh lima guru bimbingan dan konseling SMA Negeri di Kabupaten Kubu Raya, hasil dari analisis model digunakan untuk melakukan perbaikan pada model hipotetik yang kemudian dikembangkan. 


\section{HASIL DAN PEMBAHASAN}

\section{Gambaran Pelaksanaan Layanan Informasi di SMA Negeri Kubu Raya}

\section{Tujuan dan Teknis Pelaksanaan dalam Perencanaan Layanan Informasi Karier}

Program layanan informasi karier telah terencana, mulai dari program tahunan sampai dengan program mingguan. Perencanaan program didasarkan pada need assesment yaitu berdasarkan DCM dan yang diberikan kepada siswa saat awal masuk/saat awal tahun ajaran. Seperti yang disampaikan oleh koordinator bimbingan dan konseling (HV) yang mengatakan bahwa program layanan informasi secara administrasi sudah dipersiapkan untuk pelaksanaan kegiatan dalam layanan bimbingan dan konseling, namun sasaran layanan kegiatan informasi belum terdata cukup baik karena hanya tertuju pada penyampaian materi sesuai Standar Kompetensi Kemandirian Peserta Didik /SKKPD (hasil wawancara dari koordinator BK/konselor). Senada dengan apa yang diungkapkan oleh salah satu guru bimbingan dan konseling (MR) yang mengatakan bahwa pelaksanaan layanan informasi sendiri bersifat terjadwal yaitu dilaksanakan sesuai dengan alokasi yang telah ditetapkan yakni 45 menit pembelajaran setiap 1 minggu sekali, sehingga belum dikatakan cukup untuk menyampaikan wawasan pemahaman terhadap konsep materi informasi yang hendak dibahas dan kadang tidak tuntas. Sedangkan untuk tujuan layanan informasi masih sebatas tujuan umum yaitu untuk membantu memberikan pemahaman kepada siswa secara klasikal. Serta dalam hal anggaran pelaksanaan layanan informasi tidak direncanakan anggarannya secara jelas dan jika memang diperlukan adanya biaya pelaksanaan layanan informasi maka akan dipenuhi sewaktu-waktu pelaksanaan layanan informasi memerlukan anggaran (hasil wawancara dari guru BK/konselor).

\section{Pelaksanaan Layanan Informasi Karier}

Pelaksanaan layanan informasi adalah: kapan dan dimana tempat dilaksanakannya kegiatan layanan informasi, tujuan diadakannya layanan informasi serta bagaimana model pelaksanaan layanan informasi yang sudah berjalan selama 
ini. Hasil yang diperoleh adalah: karena keterbatasan waktu maka pelaksanaan layanan informasi dengan kelompok besar seringkali memanfaatkan ruanganruangan kosong seperti ruang aula atau perpustakaan, sedangkan pelaksanaannya sendiri yang non terjadwal masih bersifat insidental yaitu dilaksanakan hanya ketika dibutuhkan atau memang perlu dilaksanakan serta model pelaksanaan layanan informasi yang masih konvensional dan bersifat klasikal dalam pemecahan masalahnya. Seperti yang disampaikan oleh salah satu guru bimbingan dan konseling (MR) yang mengatakan bahwa layanan informasi yang selama ini dilaksanakan pada umumnya menggunakan teknik ceramah atau satu arah untuk menyampaikan materi atau informasi yang dibahas dalam kelas tersebut (hasil wawancara dari koordinator $\mathrm{BK} /$ konselor). Tahapan dalam kegiatan layanan informasi yang dilaksanakan mengacu kepada prosedur operasional standar pelaksanaan layanan informasi dalam BK Komprehensif yaitu dengan empat tahap yaitu: tahap perencanaan, tahap pelaksanaan, tahap evaluasi dan tahap tindak lanjut. Karena hanya menggunakan teknik ceramah dan hanya sekali dalam seminggu pertemuan yang dilaksanakan, maka siswa cenderung merasa tidak nyaman dan acapkali tidak serius dalam mendengarkan dan kadangkala materi yang dibahas tidak tuntas (hasil wawncara dari koordinator dan guru BK/konselor).

\section{Fokus Intervensi dan Masalah yang Dibahas dalam Layanan Informasi}

Materi atau masalah yang dibahas sudah sesuai dengan kebutuhan siswa karena membahas materi berdasarkan pedoman pelaksanaan layanan bimbingan dan konseling SMA. Sedangkan topik yang dibahas ketika pelaksanaan layanan informasi sering menggunakan materi langsung dari guru bimbingan dan konseling serta kurang semangatnya siswa ketika diajak berdiskusi untuk berdiskusi permasalahan dalam kegiatan layanan informasi. Mengenai masalah pemantapan karier sudah pernah dibahas, namun tidak terkonsep secara matang dan tidak secara khusus dirancang dengan teknik yang tepat dan yang dibutuhkan dalam satuan materi bakat dan minat. Dalam pelaksanaan layanan informasi di sekolah tersebut sudah terprogram sesuai pedoman SKKPD. Ketika ada masalah saja baru 
dilaksanakan layanan tambahan dengan menerapkan layanan konseling individual maupun layanan kelompok.

\section{Tenaga atau Sumber Daya Manusia}

Kualifikasi pendidikan semua guru bimbingan dan konseling di sekolah tempat penelitian adalah berlatar belakang bimbingan dan konseling, karena semua guru adalah berlatar belakang pendidikan bimbingan dan konseling, jadi kegiatan bimbingan dan konseling idelanya sudah efektif secara umum. Penguasaan guru pembimbing terhadap pelaksanaan layanan informasi masih perlu ditingkatkan. Karena guru pembimbing belum menguasai secara jelas standar prosedur operasional pelaksanaan layanan informasi dan masih bertahan dengan satu metode pasif yang menurut pengalaman konselor pada waktu terdahulu, bisa dilaksanakan lebih variatif serta dianggap memberikan hasil yang optimal (hasil wawancara dari kepala sekolah).

\section{Waktu Pelaksanaan Layanan Informasi}

Layanan informasi dilaksanakan sesuai alokasi waktu yang dijadwalkan selama satu jam pelajaran berkisar 45 menit dalam proses pelaksanaan layanan informasi rutin klasikal 1 kali dalam satu minggu, dan keterbatasan waktu yang sangat kurang sekali karena tidak diberikan jam masuk kelas untuk guru BK oleh kepala sekolah di luar jadwal tersebut sehingga kadangkala menggunakan tambahan waktu setiap hari jumat sore selama 60 menit bersamaan dengan pelaksanaan kegiatan pembinaan diri siswa oleh pihak Waka Kesiswaan (hasil wawancara dari koordinator BK/konselor).

\section{Faktor Berpengaruh dan Sarana dalam Pelaksanaan Layanan Informasi}

Guru BK di SMA Negeri 1 Sungai Kakap, Kabupaten Kubu Raya sudah memiliki kantor khusus guru BK namun sarana yang dimiliki kurang memadai, hanya meja guru pembimbing dan ruang tamu. Belum memiliki ruangan khusus untuk kegiatan konseling individual dan kelompok, sedangkan untuk layanan 
informasi memanfaatkan ruang kelas serta ruang aula atau ruang media. (hasil wawancara dari koordinator BK/konselor). Sedangkan untuk keterbatasan adalah pada pelaksanaan analisis kebutuhan terhadap materi layanan informasi, selama ini dilakukan namun tidak benar-benar diolah dan dilaksanakan secara tuntas.

\section{Evaluasi dan Tindak Lanjut}

Evaluasi layanan informasi yang sudah dilaksanakan di sekolah hanya sebatas pada tahap pemahaman dan penilaian segera. Sesuai dengan apa yang disampaikan oleh koordinator bimbingan dan konseling (HV) yang mengatakan bahwa untuk menilai hasil dari pelaksanaan layanan informasi kami belum sampai pada tahap penilaian jangka panjang, disebabkan pelaksanaan layanan informasi dilaksanakan sebatas menjalankan program dan tidak memiliki andil dalam penilaian sikap siswa. Layanan informasi telah terencana dalam program bimbingan konseling, namun dalam pelaksanaannya sering kali tidak sesuai dengan rencana. Pelaksanaannya masih menggunakan cara-cara konvensional yaitu hanya dengan ceramah dan diskusi tanpa mempertimbangkan teknik yang tepat untuk membantu siswa dalam mencapai pemahaman dalam penemuan dan penerapan perilaku serta jalan keluar permasalahan secara tepat. Pembahasan tentang kualifikasi pendidikan guru bimbingan dan konseling di tempat penelitian, memberikan gambaran bahwa ada 3 guru BK yang berkualifikasi bimbingan dan konseling sudah efektif dalam membantu siswa dalam pelaksanaan layanan informasi sehingga tidak perlu penambahan guru BK lagi, dan perlu dibicarakan yang lebih serius terhadap kepala sekolah untuk memberikan jam khusus tambahan untuk guru BK. Maka perlu ditingkatkan penguasaan mengenai pelaksanaan prosedur layanan informasi dengan memanfaatkan teknik-teknik yang tepat dalam mengatasi permasalahan siswa sehingga hasil dari pelaksanaan layanan informasi dapat berhasil secara optimal (hasil wawancara dari koordinator BK/konselor).

\section{Gambaran Pemantapan Karier Siswa}

Gambaran tentang kondisi keterampilan sosial siswa di SMA Negeri 1 Sungai Kakap diperoleh dari hasil penyebaran skala pemahaman karier siswa dan 
observasi awal di kelas XI SMA Negeri 1 Sungai Kakap. Siswa yang menjadi subjek dalam pengambilan data ini adalah siswa kelas XI yang berjumlah 33 orang (laki-laki 12, perempuan 21). Pemilihan kelas XI sebagai subjek pengambilan data awal dengan pertimbangan: (1) kelas XI cenderung memiliki waktu yang masih panjang untuk diikutkan dalam kegiatan penelitian; (2) kelas XI menentukan jurusan yang akan diambil sehingga akan mudah untuk peneliti mengamati pola sikap pemahaman karier siswa yang dimikinya. Berikut ini merupakan hasil dari observasi kondisi awal pemhaman karier siswa dapat dilihat pada tabel 1.

Tabel 1. Deskripsi Hasil Observasi Kelas XI SMA Negeri 1 Sungai Kakap

\begin{tabular}{|c|l|c|c|l|}
\hline No & Jenis Kelamin & $\begin{array}{c}\text { Skor } \\
\%\end{array}$ & Kat & \multicolumn{1}{|c|}{ Kesimpulan Pengamatan } \\
\hline 1 & Laki-laki (LK) & $\begin{array}{c}10 \\
75 \%\end{array}$ & $\mathrm{~S}$ & $\begin{array}{l}\text { Siswa ketika guru pembimbing menyampaikan materi } \\
\text { tampak bersantai dan tidak serius dalam mengikuti } \\
\text { materi yang disampaikan. Siswa berbincang dengan } \\
\text { teman sebangkunya dengan menggunakan bahasa- } \\
\text { bahasa seharian, pada saat ditanya tentang materi sulit } \\
\text { untuk menjawab, belum memahami potensi dirinya. }\end{array}$ \\
\hline 2 & $\begin{array}{l}\text { Perempuan } \\
\text { (PR) }\end{array}$ & 8 & $\mathrm{~K}$ & $\begin{array}{l}\text { Siswa masih cenderung menampilkan sikap yang tidak } \\
\text { menghargai guru ketika berbicara di depan kelas, } \\
\text { mereka masih sibuk dengan hal lain diluar pelajaran } \\
\text { dan berbicara dengan teman lainnya sehingga terkesan } \\
\text { tidak mampu menempatkan situasi dan diri. Siswa } \\
\text { kurang memiliki semangat dalam mengikuti layanan, } \\
\text { tidak paham dengan potensi diri, dan sulit menentukan } \\
\text { jurusan dan pekerjaan nanti (tidak memiliki cita-cita). }\end{array}$ \\
\hline $\begin{array}{l}\text { Total Skor } \\
\%\end{array}$ & $\begin{array}{l}18,25 \% \\
65,62\end{array}$ & & \\
\hline
\end{tabular}

Hasil observasi di atas menggambarkan bahwa siswa sebelum layanan informasi berbantu media visual untuk meningkatkan pemahaman karier dilaksanakan masih cenderung dalam kategori sedang (LK) dan kategori kurang (PR), hal ini ditunjukkan melalui ketiadaan kemampuan memahami potensi diri, ketidakmampuan cara menentukan jurusan, sikap yang tidak bersemangat dalam bekerja, dan kemampuan problem solving yang memiliki besaran 18 point dan persentase sebesar 65,62 \%. Visualisasi kondisi pemahaman karier siswa di awal sebelum perlakuan dapat dilihat pada gambar 2 . 


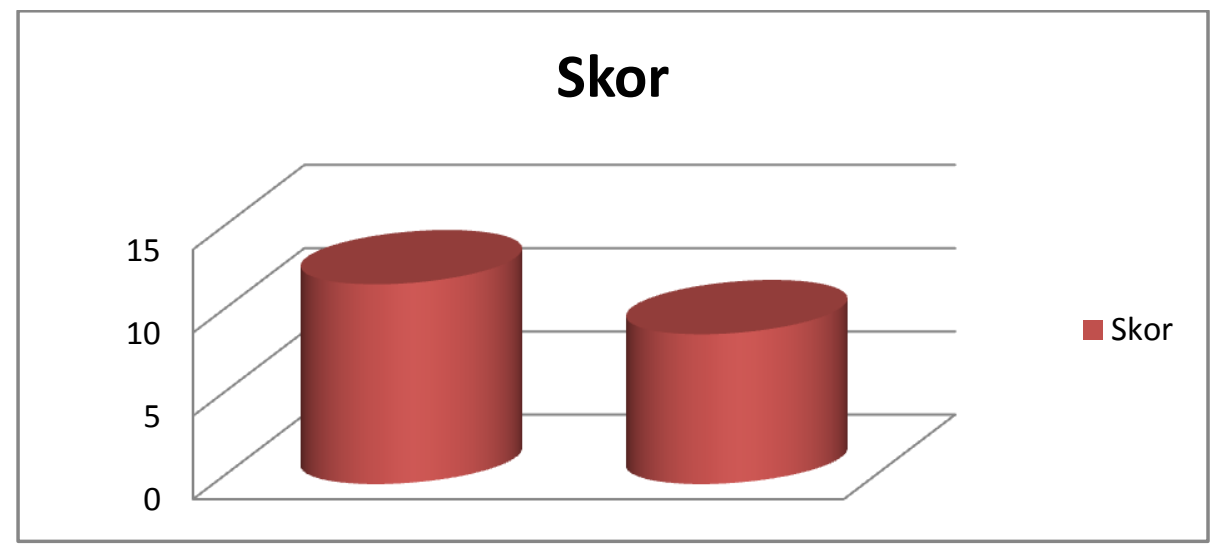

Gambar 2. Observasi Kondisi Pemahaman Karier

\section{Hasil Pengembangan: Model Layanan Informasi Karier berbantu Media Visual untuk Meningkatkan Pemantapan Karier pada Siswa SMA Negeri Kabupaten Kubu Raya}

Model layanan informasi karier yang dikembangkan berisi 6 komponen utama, yakni: (a) Rasional yang menjelaskan secara terperinci tentang alasan peneliti dalam mengembangkan model layanan informasi karier. (b) Tujuan yang ingin dicapai dari pengembangan model. Tujuan ini dibagi menjadi 2, yakni tujuan umum dan tujuan khusus. (c) Asumsi dari isi layanan informasi yang berfokus pada keterampilan sosial (d) Target intervensi adalah siswa yang sudah atau belum baik dalam pemahaman terhadap kemantapan karier. (e) Kompetensi penunjang layanan informasi yang terdiri dari kemampuan merencanakan, melaksanakan, mengevaluasi dan melakukan tindak lanjut layanan informasi yang hendak disampaikan. Kompetensi penunjang yang tidak kalah penting dalam memberikan layanan informasi yang dibutuhkan adalah kemampuan berkomunikasi persuasive serta memiliki daya pemahaman yang tinggi terhadap materi yang hendak disampaikan dalam kelompok besar maupun dalam leaflet, papan bimbingan yang disusun sebagai media perantara. Kompetensi lainnya adalah penguasaan terhadap dunia kerja, agar dapat menyampaikan konsep karier dengan media visual sesuai dengan tujuan yang ditetapkan dan hendak dicapai. (f) Langkah penyajian, layanan informasi menggunakan media visual yang terdiri dari tujuan dan isi, sasaran layanan, teknik penyampaian, waktu dan tempat pelaksanaan, dan indikator keberhasilan. 
Hasil akhir dari pengembangan model layanan informasi karier berbantu media visual untuk meningkatkan pemantapan karier pada siswa SMA Negeri Kabupaten Kubu Raya dapat dilihat pada tabel 2.

\section{Tabel 2. Desain Model Hipotetik Akhir Layanan Informasi Karier Menggunakan Media Visual}

\begin{tabular}{|c|c|c|}
\hline \multicolumn{3}{|r|}{ Model Akhir } \\
\hline No & Komponen & Penjelasan \\
\hline 1 & Rasional & $\begin{array}{l}\text { Pelaksanaan layanan informasi menggunakan media visual } \\
\text { bertujuan untuk merubah pikiran irasional menjadi rasional serta } \\
\text { merubah perilaku negatif menjadi positif dalam menentukan karier. }\end{array}$ \\
\hline 2 & Tujuan & $\begin{array}{l}\text { 1. Secara umum tujuan layanan informasi karier menggunakan } \\
\text { media visual adalah untuk meningkatkan pemantapan karier } \\
\text { siswa. } \\
\text { 2. Secara khusus tujuan layanan informasi menggunakan media } \\
\text { visual dilaksanakan secara klasikal adalah agar siswa kompeten } \\
\text { dalam hal, sebagai berikut: mengembangkan pemahaman } \\
\text { terhadap potensi diri, kemampuan menyesuaikan diri, } \\
\text { kemampuan menentukan pilihan karier, serta kemampuan } \\
\text { problem solving. }\end{array}$ \\
\hline 3 & Asumsi & $\begin{array}{l}\text { Layanan informasi adalah pengembangan dan pencegahan } \\
\text { masalah, yang menjunjung tinggi nilai-nilai dan potensi } \\
\text { kemanusiaan dalam berbagai bentuk. Sehingga layanan } \\
\text { informasi merupakan pemberian bantuan kepada siswa dalam } \\
\text { mengembangkan seluruh potensi untuk mengoptimalkan } \\
\text { pencapaian tugas-tugas perkembangan, mencegah kondisi yang } \\
\text { dapat menghambat perkembangan, dan memperbaiki atau } \\
\text { menjembatani kesenjangan antara perkembangan aktual dengan } \\
\text { perkembangan yang diharapkan. }\end{array}$ \\
\hline 4 & $\begin{array}{c}\text { Target dan Isi } \\
\text { Layanan } \\
\text { Informasi }\end{array}$ & $\begin{array}{l}\text { Model layanan informasi berbantu media visual untuk } \\
\text { meningkatkan pemantapan karier berhubungan dengan masalah } \\
\text { pribadi, dan karier. Sedangkan dalam masalah karier khususnya, } \\
\text { layanan informasi dapat membantu siswa memperoleh pemahaman } \\
\text { tentang cita-cita, potensi diri, dan menentukan jurusan yang sesuai } \\
\text { dengan skill. }\end{array}$ \\
\hline 5 & $\begin{array}{l}\text { Kompetensi } \\
\text { Penunjang }\end{array}$ & $\begin{array}{l}\text { Komponen pendukung sistem adalah kegiatan-kegiatan manajemen } \\
\text { yang bertujuan untuk memantapkan, memelihara, dan }\end{array}$ \\
\hline
\end{tabular}




\begin{tabular}{|c|c|c|}
\hline & & $\begin{array}{l}\text { meningkatkan program layanan informasi dalam hal ini adalah } \\
\text { program layanan informasi berbantu media visual untuk } \\
\text { meningkatkan pemantapan karier . Kompetensi yang dibutuhkan } \\
\text { oleh seorang pemberi layanan terdiri dari kemampuan } \\
\text { merencanakan, melaksanakan, mengevaluasi dan melakukan tindak } \\
\text { lanjut layanan informasi yang hendak disampaikan. Kompetensi } \\
\text { penunjang yang tidak kalah penting dalam memberikan layanan } \\
\text { informasi yang dibutuhkan adalah kemampuan berkomunikasi } \\
\text { persuasive serta memiliki daya pemahaman yang tinggi terhadap } \\
\text { materi yang hendak disampaikan dalam kelompok besar maupun } \\
\text { dalam leaflet, papan bimbingan yang disusun sebagai media } \\
\text { perantara. Kompetensi lainnya adalah pemahaman terhadap dunia } \\
\text { kerja menggunakan media visual yang menarik, agar dapat } \\
\text { menyampaikan konsep karier yang sesuai dengan tujuan yang } \\
\text { ditetapkan dan hendak dicapai. }\end{array}$ \\
\hline 6 & $\begin{array}{c}\text { Langkah } \\
\text { Pelaksanaan } \\
\text { Layanan } \\
\text { Informasi Karier } \\
\text { Berbantu Media } \\
\text { Visual }\end{array}$ & $\begin{array}{l}\text { 1. Tahap perencanaan, penetapan tujuan, sasaran layanan, teknik } \\
\text { penyajian, dan waktu serta tempat kegiatan } \\
\text { 2. Tahap pelaksanaan: Kegiatan Awal, Inti, Penutup } \\
\text { 3. Tahap Evaluasi } \\
\text { 4. Tindak Lanjut }\end{array}$ \\
\hline
\end{tabular}

\section{Peningkatan Pemantapan Karier Siswa Setelah dilaksanakan Layanan Informasi Karier berbantu Media Visual}

Peningkatan pemantapan karier siswa dapat dilihat pada tabel 3.

Tabel 3 Peningkatan pemantapan karier siswa kelas XI SMA Negeri 1 Sungai Kakap

\begin{tabular}{|c|c|c|c|c|c|c|c|}
\hline \multirow{3}{*}{$\begin{array}{c}\text { Evaluasi } \\
\text { Awal }\end{array}$} & Kelas & $\begin{array}{c}\text { Frekuensi } \\
\%\end{array}$ & Kategori & \multirow{3}{*}{$\begin{array}{c}\text { Evaluasi } \\
\text { Akhir }\end{array}$} & $\begin{array}{c}\text { Frekuensi } \\
\%\end{array}$ & Kategori & Pen \\
\hline & $\begin{array}{l}\text { Laki-laki } \\
\text { (LK) }\end{array}$ & $\begin{array}{c}10 \\
75 \%\end{array}$ & $S$ & & $\begin{array}{c}15 \\
83 \%\end{array}$ & $\mathrm{~T}$ & $\begin{array}{c}5 \\
1,26\end{array}$ \\
\hline & $\begin{array}{l}\text { Perempuan } \\
\text { (PR) }\end{array}$ & $\begin{array}{c}8 \\
56,25 \%\end{array}$ & $\mathrm{~K}$ & & $\begin{array}{c}10 \\
75 \%\end{array}$ & $S$ & $\begin{array}{c}2 \\
0,67\end{array}$ \\
\hline
\end{tabular}

Berdasarkan tabel di atas terlihat bahwasanya pemantapan karier siswa mengalami 
peningkatan (nilai evaluasi akhir lebih tinggi dari nilai evaluasi awal). Ketercapaian hasil tersebut karena kegiatan layanan informasi berbantu media visual telah dilaksanakan secara professional sesuai dengan prosedur yang telah direncanakan, walaupun terjadi beberapa hambatan saat kegiatan berlangsung. Faktor-faktor yang mendukung pemantapan karier siswa antara lain: (a) Guru pembimbing/pelaksana penelitian dapat berperan sebagai motivator dengan berupaya mampu mengoptimalkan kemampuan resolusi konflik, tidak hanya pada diri sendiri tapi juga pada siswa lain, menyelipkan kemampuan meredam dan mengelola kelas menggunakan media visual yang menarik dalam pelaksanaan layanan. (b) Materi yang menjadi topik bahasan, yakni tentang karier yang disandingkan dengan pemahaman dan pemantapan karier sesuai dengan tingkat kebutuhan siswa pada umumnya dan siswa pada khususnya. (c) Guru pembimbing/pelaksana penelitian sebagai perencana kegiatan mampu memberikan perlakuan yang tepat sesuai dengan topik bahasan dan karakteristik siswa, yakni usia remaja. Perlakuan yang diberikan tersebut dapat menstimulus siswa untuk mengoptimalkan potensi diri sehingga mereka secara aktif menunjukan peranannya dalam menciptakan dinamika kelas. (d) Guru pembimbing/pelaksana penelitian mampu memanfaatkan berbagai sarana dan prasarana yang ada di SMA Negeri 1 Sungai Kakap, Kabupaten kubu Raya untuk mendukung kelancaran pelaksanaan kegiatan (menggunakan ruang media visual yang menarik). (e) Pembentukan kelompok secara heterogen yang telah ada memang suah ada dan menjadi modal awal untuk mampu menumbuhkan dinamika kelompok dalam kelas dengan baik sehingga secara otomatis mampu menstimulus siswa yang awalnya pasif untuk lebih berperan aktif dalam kegiatan kelompok di kelas. Sejalan dengan penelitian Trisma, S (2013) dengan judul penerapan layanan informasi karier dengan menggunakan media flashcard untuk meningkatkan kemantapan perencanaan karier siswa kelas XI SMA Negeri 11 Surabaya. Hasil penelitian menunjukkan adanya peningkatan kemantapan perencanaan karier siswa yang semula mengalami tidak mengetahui bakat dan minat yang terdapat dalam dirinya, tidak mengetahui kelebihan dan kekurangan diri, tidak mengetahui berbagai macam jenis pekerjaan dan peluang pekerjaan yang terdapat dalam setiap jabatan, tidak mengetahui berbagai macam bentuk dan 
jurusan di perguruan tinggi serta tidak mampu menentukan perencanaan karier yang sesuai dengan cita-cita. Setelah memperoleh perlakuan siswa dapat mengetahui bakat dan minat, mengetahui kelebihan dan kekurangan diri, mengetahui berbagai macam jenis pekerjaan dan peluang pekerjaan yang terdapat dalam setiap jabatan, mengetahui berbagai macam bentuk dan jurusan di perguruan tinggi serta mampu menentukan perencanaan karier yang sesuai dengan cita-cita mereka.

\section{SIMPULAN}

Gambaran pelaksanaan layanan informasi karier di sekolah tempat penelitian sudah dilaksanakan secara umumnya melewati tahapan pendahuluan, kegiatan dan pengakhiran, namun belum pernah menggunakan media tertentu seperti berbantuan media visual yang merupakan media yang dapat mempermudah penyampaian informasi kepada siswa. Desain model yang dikembangkan adalah layanan informasi karier berbantuan media visual terdiri atas enam komponen, yaitu: (a) rasional, (b) tujuan layanan informasi karier, (c) asumsi, (d) target dan isi layanan informasi (e) komponen penunjang layanan informasi karier, dan (f) Langkah pelaksanaan layanan informasi karier berbantu media visual. Model layanan informasi berbantu media visual dapat digunakan sebagai upaya untuk meningkatkan pemantapan karier siswa.

\section{DAFTAR PUSTAKA}

Gladding. 2012. Konseling: Profesi yang Menyeluruh. (Alih bahasa P.M. Winarno dan Lilian Yuwono). Jakarta: PT Indeks.

Fransiska, P. 2018. "Penerapan Layanan Informasi Karier untuk Meningkatkan Pemahaman Siswa dalam Pengambilan Keputusan Karier". Jurnal Penelitian Pendidikan, 2(3), 160-170.

Richma, H. 2015. "Layanan Informasi Karier Membantu Peserta Didik dalam Meningkatkan Pemahaman Karier". Jurnal Konseling Gusjigang, 1(1), 6071.

Putu, A \& Sumaryono. 2018. "Kesuksesan Karier dan ditinjau dari Persepsi Pengembangan Karier dan Komitmen Karier pada Pekerja Milenial". Journal Of Psychology. 4(1), 57-75. 
SOSIAL HORIZON: Jurnal Pendidikan Sosial,

Vol. 7, No. 1, Juni 2020

Suherman, U. 2011. Aplikasi Konsep Bimbingan dan Konseling. Bandung: Jurusan Psikologi Pendidikan dan Bimbingan Universitas Pendidikan Indonesia.

Trisma, S. 2013. "Layanan Informasi Karier dengan Menggunakan Media Flashcard untuk Meningkatkan Kemantapan Perencanaan Karier Siswa Kelas XI SMA Negeri 11 Surabaya". Jurnal BK Unesa. 3(1), 55-63. 